\title{
The Antecedents of Relationship Marketing and Customer Loyalty: A Case of the Designed Fashion Product
}

\author{
Bui Thanh KHOA*
}

Received: December 1, 2019 Revised: December 11, 2019 Accepted: December 18, 2019

\begin{abstract}
Customer loyalty is a desired and essential result for companies in a business environment with a lot of competition, of which the fashion industry is no exception. For the fashion industry, the competition between businesses is increasingly fierce with the appearance of tailored fashion brands for each customer, also known as a designed fashion brand. The objective of this study is to examine the relationship between the antecedents of the relationship (reputation of designer, social media marketing) and customer relationship (trust and intimacy), and loyalty of customer for a designed fashion brand. The mixed research method is used to achieve research objectives with qualitative and quantitative research method. Qualitative data was collected through in-depth interview with 12 participants in Ho Chi Minh City, while quantitative data was collected by a survey of 799 respondents in Ho Chi Minh City and Hanoi City. The results show that the antecedents of relationship marketing positively affect on customer relationship and customer loyalty. Moreover, customer relationship has a positive impact on the customer loyalty when shopping for fashion products. From the research results, some managerial implications are also proposed for the designed fashion brands to improve the relationship marketing performance.
\end{abstract}

Keywords: Reputation of Designer, Social Media Marketing, Trust, Intimacy, Customer Loyalty, Designed Fashion Product.

JEL Classification Code: M31, L81, L86

\section{Introduction}

The business considers customer retention to be a key strategy, reflecting the long-term vision. With increasing competition, the cost to attract a new customer is five or six times the cost of retaining an old customer. Therefore, businesses increasingly focus on providing existing customer-oriented services, building and implementing relationship marketing. The marketing manager must create a competitive advantage that differentiates the business in the market. Hence, a business must organize and implement marketing activities to create and maintain excellent longterm relationship with the customer, and partner inside as well as outside the organization (Kotler, Keller, Goodman,

*First Author and Corresponding Author. Ph.D. Student, Graduate School, Ho Chi Minh City Open University, Vietnam [Postal Address: 20 Street 8, Quarter 2, Hiep Binh Chanh Ward, Thu Duc District, Ho Chi Minh City, 700000, Vietnam] Tel: +84.908091402 Email: khoabt.15ab@ou.edu.vn, khoadhcn@gmail.com.

๑) Copyright: Korean Distribution Science Association (KODISA)

This is an Open Access article distributed under the terms of the Creative Commons Attribution NonCommercial License (https:///reativecommons.orglicenses/by-nc/4.0/) which permits unrestricted noncommercial use, distribution, and reproduction in any medium, provided the original work is properly cited.
Brady, \& Hansen, 2019).

According to a 2017 survey by Asia Plus, a market research firm, Vietnamese youth now significantly increase spending on costumes. $26 \%$ of people shop for clothes $2-3$ times per month, $52 \%$ said they usually shop for clothes once a month. It is estimated that the value of Vietnamese textile and apparel consumption annually reaches about the US \$ 5-6 billion, equivalent to nearly VND 120,000140,000 billion. The business believes that the reality may be much larger, because on the market today, unknown goods, knockoffs, portable goods are also heartily consumed, especially in rural areas. Despite the potential common market, expanding market share in Vietnam is not easy for both foreign and domestic enterprises. Foreign fashion brands quickly gained success in some big cities; most of them stopped moving to other provinces due to the high price and style that did not suit the tastes of the Vietnamese people. The expanding journey of Vietnamese fashion brands is even more arduous when many consumers still prefer unknown products, knockoffs (Tu, 2019). The fashion market is changing a lot in recent year, besides large enterprises with well-known brand, a series of 
individual fashion brands with a designed fashion product strategy are also born and compete fiercely with major brands. However, for large businesses, they have the financial strength to conduct marketing activities such as competitive pricing, multiple distribution channels, and appropriate marketing policies. Therefore, the best solution for designed fashion brands with low finance is to invest in a long-term customer relationship (Adamson, Chan, \& Handford, 2003; Nguyen \& Khoa, 2019c).

The demand for customers' fashion is getting higher and higher as most customers have passed the low-order level of need in the demand hierarchy of Maslow (1943) (physiological need and safety need). Today, many customers have social needs, esteem needs, and self actualization needs. For modern customers, they need to go to parties, meet friends, partners every day, and get respect for others through the fashion products they wear to events. Moreover, choosing a suitable outfit, flattering body beauty, and unique is one of the factors that affirm the aesthetic capacity of each person. That is the reason why fashion followers always choose designed fashion products for themselves. For the fashion business, investing in customer relationship will improve sales efficiency (Morgan \& Hunt, 1994). Besides, the majority of research is focused on research for corporate fashion brands rather than individual fashion brands. From the reasons above, it is necessary to research the relationship between the antecedents of the relationship and customer relationship and customer loyalty in the field of designed fashion.

The remaining contents of the study will present a theoretical basis for building a conceptual model and hypotheses for the research, research methodology, research result, discussion, and conclusion.

\section{Literature Review}

\subsection{Relationship Marketing}

The marketing trend is changing a lot in modern business. Marketing is making a transition from transactional marketing to relational marketing, meaning that instead of focusing on mass marketing strategies, the businesses will pay more attention to their segment customer group or individual (Christopher, Payne, \& Ballantyne, 2013). This change creates a new concept in marketing, which is relationship marketing. There are many concepts of relationship marketing. The most general and easy to understand relationship marketing is a form of building, developing, and maintaining high-value, cost-effective relationships with customers, suppliers, employees, and partners for the benefit enduring of the two sides (Kotler et al., 2019). With the above concept, it can be seen that relationship marketing aims to build long-term relationships with stakeholders, including customers. Morgan and Hunt (1994) defined that relationship marketing encompasses all marketing activities aimed at establishing, developing, and maintaining relational communications successfully.

Relationship marketing has four methods of implementation: direct mail, direct marketing, data marketing, and customer relationship management (Egan, 2011). Direct mailing or telephone marketing is a relationship marketing based on the use of existing databases to provide one-way information to customers. This method is often used as a marketing tool with a shortterm purpose. Direct marketing also evolved from the method above but focused on marketing activities that were easier to administer and profitable. This method is heavily related to marketing communications and cross-selling of other items that customers have never purchased before. Data marketing is a method of using information technology throughout the enterprise's system to collect and store data related to past, present, and potential customers' customers. Finally, customer relationship management (CRM) is considered a personal communication channel, including direct transactions, email, phone calls, and Internet transactions. More specifically, CRM is a form of relationship marketing based on information technology application and database marketing through software.

\subsection{Customer Loyalty (LOY)}

Customer loyalty can be considered a "motivation" for business growth. It is made up of the connection between the customer, the product, and the entire business, not just a temporary desire for the price (Hennig-Thurau, Gwinner, \& Gremler, 2002). Customer loyalty is a competitive element that the competitor can not copy (Gouthier \& Schmid, 2003).

Customer loyalty to a brand indicates the tendency of customers to buy and use a particular brand in a product family and repeat this behavior (Chaudhuri, 1999). Therefore, the higher the brand that creates the loyalty of customer, the higher the profit for the company. Customer loyalty with a brand is considered the brand as the first choice among another brand in the area, and the brand that first comes to customer's minds when making purchases decisions on the brand (Bloemer, De Ruyter, \& Wetzels, 1999). Business characteristics must create and maintain the customer's desire for the brand to make the customer loyal to a brand (Jacoby \& Chestnut, 1978). Cunningham (1956) defined brand loyalty only as of the purchase share of households wholeheartedly devoted to the brands they bought it most often. Brand loyalty involves determining the frequency of purchases and the percentage of goods purchased for a brand and the probability of purchase (Day, 
1976). Some authors argue that brand loyalty (1) is a process (i.e., not accidental), (2) behavioral responses (e.g., repurchase, Word of mouth), (3) expressed over time, (4) making some basis decisions, (5) concerning one or more brands, the exclusion of such a group of brands is a function of the psychological process. Although there are many different definitions of loyalty, many authors recognize that loyalty includes both behavioral and attitudinal aspects (Day, 1976; Jacoby \& Chestnut, 1978).

\subsection{Research Model and Hypotheses}

\subsubsection{Conceptual Model}

The research of Palmatier, Dant, Grewal, and Evans (2006) has summarized and proposed the Relational Mediator Meta-Analytic Framework (RMMAF) for relationship marketing activities. The RMMAF mentions three parts, including the three main antecedents, four mediators, four moderators, and three consequences of relationship marketing. In particular, three antecedents and three consequences related to the customer-focused, sellerfocused, and both of two sides (dyadic). Four mediating constructs included commitment, trust, relationship satisfaction, and relationship quality. Moreover, four moderators include service/product-based exchange, channel/direct exchanges, business/consumer market, and individual/organizational relationship.

This study explores the elements of a fashion business that influence customer relationship, so the focus is on seller-focused and dyadic. In particular, for designed fashion brands mainly focus on fashion designers, who are the fashion brand owners. Knowledge, experience, and overall competency of the designer are the crucial factors, which impact the customer relationship (Adamson et al., 2003). The development of social networks is also one of the opportunities for business to enhance communication with customers in order to strengthen customer relationship. The use of social networking marketing is becoming a media trend in today's business context. Therefore, this research focuses on two factors of the reputation of designer (corresponding to seller experience) and social media marketing (corresponding to communication) in the RMMAF. Furthermore, the RMMAF also mentioned the mediators as trust and commitment, which are proposed by Morgan and Hunt (1994).

In the designed fashion area, fashion products need to match the personal characteristics of each customer, so trust in a fashion brand is an integral part of the relationship between the designer and the customer. Moreover, Kim and Ko (2010) also proposed intimacy as an element of the emotional relationship as commitment. Therefore, customer relationship expressed through intimacy and trust of customers for designed fashion brands. In the end, what businesses want is to capture value from their customer (Kotler et al., 2019), and that highest value is customer loyalty (Oliver, 1999). Based on the Relational Mediator Meta-Analytic Framework (Palmatier et al., 2006), the conceptual model is proposed in Figure 1.

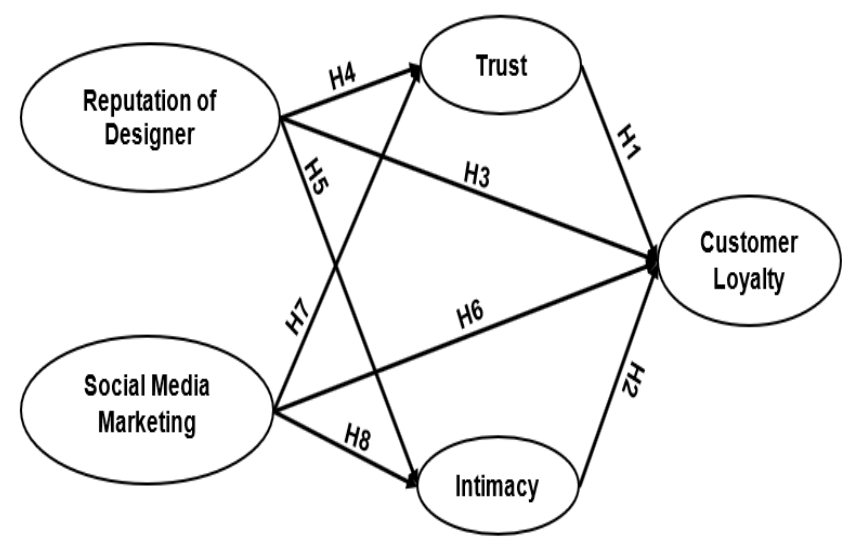

Figure 1: The conceptual model

\subsubsection{Customer Relationship}

Building relationships with customers is indispensable in a competitive business environment. The more the economy grows, the higher the competition is; hence, the more power customers have in the buying process. Gone are the days of the subsidy era, where sellers were monopolies, and buyers had no power to decide. In order to be able to do business sustainably and grow, modern business needs to take customers as a basis, as a foundation, and as leverage. The businesses need to build a good relationship with their customers, create a loyal customer base, and make the relationship bigger while at the same time finding new customers. Customer relationship is described by many dimensions, i.e., trust, commitment, relationship quality, relationship satisfaction (Morgan \& Hunt, 1994; Palmatier et al., 2006). However, in the fashion field, Kim and Ko (2010) describe customer relationship under two aspects, including trust and intimacy.

Trust can be defined at many different levels as individual and organizational. At the individual level, trust is the belief between a person with the other; at the organizational level, trust is the degree to which the member place their belief in the business or organization (Mayer, Davis, \& Schoorman, 1995). Trust is expressed in three dimensions with ability, benevolence, and integrity (Nguyen \& Khoa, 2019d). In which, Kumar and Shah (2004) stated that a person is trusty to complete as committed; understand the interests of their partners; be honest if they reflect their partners precisely what is happening on their side. 
Intimacy is the closeness, interaction, and attachment of the customer to business (Sternberg, 1997). Consumers may create an emotional relationship with a given brand, and a sense of intimacy is needed before consumers invest emotionally in the brand and develop an awareness of belief (Elliott \& Yannopoulou, 2007). Intimacy is a knowledge problem that accumulates over time and lasts longer than other emotional relationships (Carroll \& Ahuvia, 2006).

The positive behaviors of the customer, i.e., repurchasing intention, or loyalty can be created by the development of the relationship (Macintosh \& Lockshin, 1997). Customer relationship building strategy is considered as one of the main strategies to create customer loyalty (Brink \& Berndt, 2009). With a high level of trust, customers would often be loyal to the business (Chaudhuri \& Holbrook, 2001). Especially in the field of fashion, personalization is relatively high, so customers only return to a fashion store only when it meets their exact needs (Riecken, 2000). Therefore, it can be said that customer relationship is a critical antecedent to create customer loyalty when shopping at fashion stores. From there, hypotheses H1 and $\mathrm{H} 2$ are proposed.

H1: Trust has a positive effect on customer loyalty in shopping for the designed fashion product context.

H2: Intimacy has a positive effect on customer loyalty in shopping for the designed fashion product

\subsubsection{Reputation of Designer (ROD)}

The concept of reputation has long been studied in scholarly literature. However, the documents mostly refer to organizational reputation rather than personal reputation. According to Jo Hatch and Schultz (1997), the reputation of an organization is a deep awareness of the relevant objects of an organization. It is formed over a long time of understanding and evaluating the success of that organization. Business reputation is also often used as a substitute for corporate identity or image (Fombrun \& Van Riel, 1997). For individual fashion brands, the reputation of the designer is the best guarantee for that fashion brand. Kawamura (2004) has pointed out four dimensions that represent the reputation of a fashion designer, including talent, creativity, innovative designs, consistent style. Hilton, Choi, and Chen (2004) stated that the actor or actress, the customer usually choose fashion products designed by reputable designers whom they admire or believe.

The financial performance of the business is impacted by its reputation (Roberts \& Dowling, 1997). The benefit of a good reputation is to keep the customers in uncertain marketing with many competitors (Carmeli \& Tishler, 2005). Therefore, the customer will buy back or positive word of mouth about business if a fashion designer has a good reputation. Helm, Garnefeld, and Spelsiek (2015) investigate the role of perceived reputation in predicting behavior. Hence, the customer relationship is also improved. Hence, the hypothesis is proposed:

H3: Reputation of Designer has a positive effect on customer loyalty in shopping for the designed fashion product context.

H4: Reputation of Designer has a positive effect on Trust in shopping for the designed fashion product context.

H5: Reputation of Designer has a positive effect on Intimacy in shopping for the designed fashion product context.

\subsubsection{Social Media Marketing (SMM)}

Social networks have become the most convenient way to communicate between business and consumer (Turban, Outland, King, Lee, Liang, \& Turban, 2017). The development of social networking applications and the increase in the number of social network users are the good premise for businesses to deploy communication and marketing activities. By disclosing personal information on users' social networking sites, a business can easily access and exploit this free but accurate source of information (Loiacono, 2015). This behavior is also a beginning for developing a "Big Data Era" to strengthen relationships with customer.

The attributes of social media marketing are increasingly useful in reaching out, caring, and creating engagement with customers. Firstly, through the information provided by the advertising agency and online behavior as well as the disclosure of personal information on social networks, businesses can easily customize the promotion program to each customer (Bilgin, 2018). Secondly, through social networks, businesses interact with customers easily. At the same time, customers are also easy to consider, evaluate and interact with other customers (Yaakop, Anuar, \& Omar, 2013; Nguyen \& Khoa, 2019a). Thirdly, entertainment is an essential benefit to consumers (Van der Waldt, Rebello, \& Brown, 2009); customers can entertain themselves through beautiful pictures, complete information about the product (especially price and quality). Fourthly, social media marketing is one of the convenient factors to update new fashion models, news about the fashion industry; Therefore, the trend of fashion design needs to focus on working online (Godey, Manthiou, Pederzoli, Rokka, Aiello, Donvito, \& Singh, 2016). Finally, through social networking sites, customers can spread new information, such as fashion news, discount news, by sharing from the business page (Cheung, Luo, Sia, \& Chen, 2009). Entertainment in social media advertising has a positive impact on consumers' perceived value and attitude (El Ashmawy, 2014). Kim and Ko (2010) said that marketing through social media in the fashion field would have a 
positive impact on customer relationship and the intention to repurchase fashion products. According to Miller, Fabian, and Lin (2009), the importance of social media lies in the interaction between consumers and the business (Miller et al., 2009). Moreover, the increasing use of social media provides a platform to nurture brands and influence consumer buying decisions. From there, there are three hypotheses:

H6: Social media marketing has a positive effect on customer loyalty in shopping for the designed fashion product context.

H7: Social media marketing has a positive effect on Trust in shopping for the designed fashion product context.

H8: Social media marketing has a positive effect on Intimacy in shopping for the designed fashion product context.

\section{Research Methodology}

Research is conducted through two steps: (1) qualitative research, (2) and quantitative research. Qualitative research was conducted in two stages by in-depth interviews with consumers who shop the designed fashion product in 3 recent months. Qualitative research in the first phase is to explore research concepts in specific market conditions in order to generalize the research model via seven in-depth interviews. The qualitative research in the second phase is based on the scale of the research concepts of previous studies; the author conducted in-depth interviews with five participants in Ho Chi Minh City to discover customer perceptions about the available scale simultaneously. Results of qualitative research in the second phase to adjust and supplement the scales to suit the market and environmental conditions in a specific context.

The direct survey conducted quantitative research using convenient sampling methods through questionnaires for 799 respondents who own and consume the designed fashion product in 3 recent months. Survey respondents are mainly students, business owners, and office workers; who are familiar with buying fashion products (Table 1). The Smart-PLS software will process the collected data in quantitative research.

Table 1: The sample statistic

\begin{tabular}{|l|l|c|c|}
\hline \multicolumn{2}{|c|}{} & Frequency & \% \\
\hline \multirow{4}{*}{ Gender } & Male & 444 & 55.6 \\
\cline { 2 - 4 } & Female & 355 & 44.4 \\
\hline \multirow{4}{*}{ Occupation group } & $18-25$ & 204 & 25.5 \\
\cline { 2 - 4 } & $26-35$ & 182 & 22.8 \\
\cline { 2 - 4 } & $36-45$ & 232 & 29.0 \\
\cline { 2 - 4 } & Above 45 & 181 & 22.7 \\
\cline { 2 - 4 } & Student & 266 & 33.3 \\
\cline { 2 - 4 } & Office Worker & 266 & 33.3 \\
\cline { 2 - 4 } & Business Owner & 267 & 33.4 \\
\hline
\end{tabular}

The items of constructs are developed based on the original scales of previous studies and adjusted after qualitative research. The model has five research constructs with 23 items, which are measured by the 5-point Likert scale ( 1 is total disagree; 5 is total agree), which is presented in Table 2.

Table 2: The measurement scale of constructs

\begin{tabular}{|l|c|l|l|}
\hline \multicolumn{1}{|c|}{ Construct } & Item & \multicolumn{1}{c|}{ Source } & \multicolumn{1}{c|}{ The content of scale } \\
\hline Reputation of Designer & 4 & Kawamura (2004) & Talent, creativity, innovative designs, consistent style \\
\hline Social Media Marketing & 5 & Kim and Ko (2010) & Customization, entertainment, trend, interactivity, E-WOM \\
\hline Trust & 5 & Nguyen and Khoa (2019b) & $\begin{array}{l}\text { Be honest, be concerned with customer's needs, keep their } \\
\text { promise, be reliable, fulfilling customer's needs. }\end{array}$ \\
\hline Intimacy & 4 & Kim and Ko (2010) & $\begin{array}{l}\text { Closeness, connectedness, and } \\
\text { bondedness, an accurate fan }\end{array}$ \\
\hline Customer loyalty & 5 & $\begin{array}{l}\text { Bloemer } \text { et al. } \text { (1999); Hennig-Thurau } \text { et } \\
\text { al. }(2002) ; \text { Toufaily, Fallu, and Ricard } \\
(2016)\end{array}$ & $\begin{array}{l}\text { Repurchase, stable relationship, the first choice among } \\
\text { others, recommenced for the relatives, positive word-of- } \\
\text { mouth }\end{array}$ \\
\hline
\end{tabular}

\section{Results}

\subsection{Reliability and Validity Assessment}

The research will assess the reliability as well as the convergence validity and discriminant validity through the Cronbach's alpha (CA), Composite Reliability (CR), the Average Variance Extracted (AVE), and HeterotraitMonotrait Ratio (HTMT).

Cronbach's Alpha used to assess the reliability of a scale.
A reliable scale has the threshold of reliability is greater than or equal to 0.7 (Nunnally \& Bernstein, 1994). According to Table 3, the minimum of CA coefficient is 0.838 , which is more than 0.7 ; hence, all scale in research is reliability. Furthermore, Fornell and Larcker (1981) also proposed CR and AVE criteria to assess reliability and convergence value. The threshold of $\mathrm{CR}$ is greater than or equal to 0.6 , and AVE is greater than or equal to 0.5 . In this study, the minimum of CR on the scale is 0.886 , which is more than 0.6; and the lowest AVE is 0.608, which is more 
than 0.5. Consequently, all scale get reliability and convergent validity. Moreover, Hair, Hult, Ringle, and Sarstedt (2016) also proposed that the outer loadings must assess the relationship between the items and their construct. In Table 3, all outer loadings of each construct are more considerable than 0.708 . Therefore, all items are related to their construct.

Table 3: The result of CA, CR, AVE, and outer loadings

\begin{tabular}{|c|c|c|c|c|c|c|c|c|c|}
\hline & INT & LOY & ROD & SMM & TRU & CA & rho_A & CR & AVE \\
\hline INT1 & 0.880 & & & & & \multirow{4}{*}{0.910} & \multirow{4}{*}{0.911} & \multirow{4}{*}{0.937} & \multirow{4}{*}{0.789} \\
\hline INT2 & 0.869 & & & & & & & & \\
\hline INT3 & 0.930 & & & & & & & & \\
\hline INT4 & 0.872 & & & & & & & & \\
\hline LOY1 & & 0.755 & & & & \multirow{5}{*}{0.838} & \multirow{5}{*}{0.839} & \multirow{5}{*}{0.886} & \multirow{5}{*}{0.608} \\
\hline LOY2 & & 0.783 & & & & & & & \\
\hline LOY3 & & 0.721 & & & & & & & \\
\hline LOY4 & & 0.862 & & & & & & & \\
\hline LOY5 & & 0.772 & & & & & & & \\
\hline ROD1 & & & 0.830 & & & \multirow{4}{*}{0.875} & \multirow{4}{*}{0.878} & \multirow{4}{*}{0.915} & \multirow{4}{*}{0.729} \\
\hline ROD2 & & & 0.792 & & & & & & \\
\hline ROD3 & & & 0.922 & & & & & & \\
\hline ROD4 & & & 0.867 & & & & & & \\
\hline SMM1 & & & & 0.930 & & \multirow{5}{*}{0.938} & \multirow{5}{*}{0.940} & \multirow{5}{*}{0.953} & \multirow{5}{*}{0.802} \\
\hline SMM2 & & & & 0.906 & & & & & \\
\hline SMM3 & & & & 0.894 & & & & & \\
\hline SMM4 & & & & 0.893 & & & & & \\
\hline SMM5 & & & & 0.854 & & & & & \\
\hline TRU1 & & & & & 0.887 & \multirow{5}{*}{0.869} & \multirow{5}{*}{0.870} & \multirow{5}{*}{0.906} & \multirow{5}{*}{0.659} \\
\hline TRU2 & & & & & 0.752 & & & & \\
\hline TRU3 & & & & & 0.827 & & & & \\
\hline TRU4 & & & & & 0.835 & & & & \\
\hline TRU5 & & & & & 0.748 & & & & \\
\hline
\end{tabular}

Note: Cronbach's Alpha (CA), Composite Reliability (CR), the Average Variance Extracted (AVE).

Lastly, Heterotrait-Monotrait Ratio (HTMT) is used to assess the discriminant validity between the constructs in the conceptual model (Hair et al., 2016). The thresholds of HTMT must be less than 0.85 . The highest value of HTMT in table 4 is 0.845 . Therefore, there is the discriminant validity between the constructs in this research.

\subsection{Partial Least Squares Structural Equation Modeling (PLS-SEM)}

Some criteria to test the reliability of PLS-SEM results are VIF value, $\mathrm{R}^{2}$ value, $\mathrm{f}^{2}$ value, and $\mathrm{Q}^{2}$ value (Hair et al.,
2016). Firstly, all VIF values are lower than 5.0; the maximum of VIF in Table 5 is 2.122; hence, the collinearity issue does not raise a concern in the conceptual model.

Table 4: The result of HTMT value

\begin{tabular}{|c|c|c|c|c|c|}
\hline & INT & LOY & ROD & SMM & TRU \\
\hline INT & & & & & \\
\hline LOY & 0.813 & & & & \\
\hline ROD & 0.472 & 0.821 & & & \\
\hline SMM & 0.516 & 0.797 & 0.477 & & \\
\hline TRU & 0.633 & 0.845 & 0.704 & 0.596 & \\
\hline
\end{tabular}

Table 5: The result of VIF, $\mathrm{R}^{2}, \mathrm{f}^{2}$, and $\mathrm{Q}^{2}$.

\begin{tabular}{|c|c|c|c|c|c|c|c|c|}
\hline & \multicolumn{3}{|c|}{ VIF } & \multirow{2}{*}{$\mathbf{R}^{2}$} & \multicolumn{2}{c|}{$\mathbf{f}^{2}$} & \multirow{2}{*}{$\mathbf{Q}^{2}$} \\
\hline & INT & LOY & TRU & & INT & LOY & TRU & 0.208 \\
\hline INT & & 1.573 & & 0.285 & & 0.353 & 0.456 \\
\hline LOY & & & & 0.809 & & & \\
\hline ROD & 1.229 & 1.652 & 1.229 & & 0.080 & 0.355 & 0.335 & \\
\hline SMM & 1.229 & 1.530 & 1.229 & & 0.149 & 0.345 & 0.176 & \\
\hline TRU & & 2.122 & & 0.470 & & 0.066 & & 0.282 \\
\hline
\end{tabular}


According to Hair et al. (2016), Partial Least Squares Structural Equation Modeling (PLS-SEM) should bootstrap with 5000 random subsamples. All independent constructs have a positive impact significantly on the dependent constructs with the p-value is less than 0.001 (Table 6). Therefore, all hypotheses are supported.

Table 6: PLS-SEM result

\begin{tabular}{|c|c|c|c|c|c|}
\hline & $\boldsymbol{\beta}$ & STDEV & P Values & Hypothesis & Result \\
\hline TRU -> LOY & 0.163 & 0.030 & 0.000 & H1 & Supported \\
\hline INT -> LOY & 0.325 & 0.027 & 0.000 & H2 & Supported \\
\hline ROD -> LOY & 0.335 & 0.026 & 0.000 & H & Supported \\
\hline ROD -> TRU & 0.467 & 0.040 & 0.000 & Supported & Supported \\
\hline ROD -> INT & 0.265 & 0.043 & 0.000 & H6 & Supported \\
\hline SMM -> LOY & 0.317 & 0.025 & 0.000 & H7 & Supported \\
\hline SMM -> TRU & 0.339 & 0.034 & 0.000 & H8 & Supported \\
\hline SMM -> INT & 0.362 & 0.042 & 0.000 & &
\end{tabular}

Note: Original Sample ( $\beta$ ), Standard Deviation (STDEV)

\section{Discussion}

The research results meet academic and practical implications, especially for fashion. Quantitative research results support all research hypotheses, specifically as follows: Customer relationship positively influence customer loyalty to a specifically designed fashion brand. In particular, customer trust $(\beta=0.163)$ has a less positive effect on customer loyalty than intimacy $(\beta=0.325)$. Hence, the hypothesis $\mathrm{H} 1$ and $\mathrm{H} 2$ are supported. These results are consistent with the Relational Mediator Meta-Analytic Framework and the theory of relational marketing when trust and intimacy have a positive influence on customer behavior such as positive word of mouth or repurchase (Morgan \& Hunt, 1994; Palmatier et al., 2006). In particular, for designed fashion products, the closeness, understanding of the customers' desire is what most customers want. It will lead them to behavior or loyalty to a designer in the future. In a qualitative interview, some respondents said: "they return to a fashion store, because of the sincerity, and the designers' understanding of their dress style." Elliott and Yannopoulou (2007) have also shown that customer can create an emotional relationship with a brand before investing emotionally and developing positive awareness or behavior with the brand. The accumulation of intimacy will create a more lasting bond than previous romantic relationships (Sternberg, 1997; Carroll \& Ahuvia, 2006).

The reputation of the designer has a positive effect on customer loyalty $(\beta=0.335)$, trust $(\beta=0.467)$ and intimacy $(\beta=0.265)$. Therefore, hypotheses $\mathrm{H} 3, \mathrm{H} 4$, and $\mathrm{H} 5$ are also supported. In particular, reputation has the greatest impact on customers' trust in fashion designer brands. This result is agreed upon by many other researchers (Fombrun \& Van Riel, 1997; Helm et al., 2015). The reputation of the designer is also factors that influence the customer's repurchase intention at a fashion store in the future (Weigelt
\& Camerer, 1988; Walsh \& Beatty, 2007; Ismail, 2017). The reputation of the designer is a guarantee of the buyer's class. That is why many customers choose a fashion brand based on the reputation of the designer. Many customers feel more confident and stylish when wearing products created by reputable designers.

The growing social network has created many advantages for designed fashion brands to reach customers more easily. Research has shown that social media marketing has a positive influence on loyalty $(\beta=0.317)$, trust $(\beta=0.339)$, and intimacy $(\beta=0.362)$ in the field of fashion; in particular, intimacy is the largest influenced by the social media marketing. All hypotheses H6, H7, H8, are accepted. Reaching customers easily by providing exactly the content they are interested in, delivering the right trendy, entertaining messages. Besides, business can take advantage of social networks to create communities for customers to discuss, which is an advantage to influence customer relationship. At the same time, answering questions, or taking care of customers will create a positive attitude of customers towards the brand and lead to return behavior. Many studies also agree with the impact of social media marketing on building a relationship with customer (Kim \& Ko, 2010; Ismail, 2017).

\section{Conclusion}

The seemingly disproportionate competition between industrial fashion brands and individual designer brands has led to demands in finding competitive solutions for designed fashion brands. This research has shown the positive relationship between designer reputation and social media marketing to trust, intimacy, and customer loyalty in the fashion market. Thereby, to increase competitiveness, fashion design businesses need to have solutions to increase 
customer loyalty related to social media marketing and reputation. In particular, creating customer relationship is also an important factor affecting customer loyalty. Building and developing core services is a critical strategy in relationship marketing aimed at establishing customer relationship around core services. An ideal core service is one that can attract customers through characteristics that meet the needs and expectations of customers. Personalizing the relationship with each customer by understanding the specific characteristics and requirements of each customer, then putting all the information into the database and retrieving it when needed. Besides, the ability to conduct surveys on tastes and habits of consumers is also an essential key that designed fashion businesses must learn in the context of the increasingly shorter fashion life cycle of today's products. This fact has forced global fashion corporations to invest more heavily in Big Data technology. Big Data helps retailers to orient from the beginning which products need to be produced, how much, and when to reduce prices.

This research still has some limitations that can be completed by further studies. The fashion market is growing day by day with the development of society, so the addition of antecedents such as relationship benefits, or the fashion store atmosphere is a necessity. Besides, further studies may make comparisons between industrial fashion brands and individual fashion brands so that the differences between the two objects can be discovered.

\section{Reference}

Adamson, I., Chan, K.-M., \& Handford, D. (2003). Relationship marketing: customer commitment and trust as a strategy for the smaller Hong Kong corporate banking sector. International Journal of Bank Marketing, 21(6/7), 347-358. https://doi.org/10.1108/02652320310498492

Bilgin, Y. (2018). The effect of social media marketing activities on brand awareness, brand image and brand loyalty. Business \& Management Studies: An International Journal, 6(1), 128-148. https://doi.org/10.15295/bmij.v6i1.229

Bloemer, J., De Ruyter, K., \& Wetzels, M. (1999). Linking perceived service quality and service loyalty: a multidimensional perspective. European journal of marketing, 33(11/12), 1082-1106. https://doi.org/10.1108/03090569910292285

Brink, A., \& Berndt, A. (2009). Relationship marketing and customer relationship management. Cape Town, South Africa: Juta and Company Ltd.

Carmeli, A., \& Tishler, A. (2005). Perceived organizational reputation and organizational performance: An empirical investigation of industrial enterprises. Corporate Reputation Review, 8(1), 13-30. https://doi.org/10.1057/palgrave.crr.1540236

Carroll, B. A., \& Ahuvia, A. C. (2006). Some antecedents and outcomes of brand love. Marketing letters, 17(2), 79-89. https://doi.org/10.1007/s11002-006-4219-2

Chaudhuri, A. (1999). The Relationship of Brand Attitudes and Brand Performance: The Role of Brand Loyalty. Journal of Marketing Management, 9(3), 1-9.

Chaudhuri, A., \& Holbrook, M. B. (2001). The chain of effects from brand trust and brand affect to brand performance: the role of brand loyalty. Journal of marketing, 65(2), 81-93.

https://doi.org/10.1509/jmkg.65.2.81.18255

Cheung, M. Y., Luo, C., Sia, C. L., \& Chen, H. (2009). Credibility of electronic word-of-mouth: Informational and normative determinants of on-line consumer recommendations. International journal of electronic commerce, 13(4), 9-38. https://doi.org/10.2753/JEC1086-4415130402

Christopher, M., Payne, A., \& Ballantyne, D. (2013). Relationship marketing: creating stakeholder value. Oxford, U.K.: Routledge. https://doi.org/10.4324/9780080516042

Cunningham, R. M. (1956). Brand loyalty-what, where, how much. Harvard Business Review, 34(1), 116-128.

Day, G. S. (1976). A two-dimensional concept of brand loyalty. In Mathematical models in marketing (pp. 8989). Berlin, Germany: Springer.

Egan, J. (2011). Relationship marketing: Exploring relational strategies in marketing (4th ed.). Harlow, England: Financial Times/Prentice Hall.

El Ashmawy, M. (2014). Measuring the University Students' Attitude toward Facebook Advertising ( $\mathrm{PhD}$ Thesis). Arab Academy for Science, Technology and Maritime Transport, Alexandria, Egypt.

Elliott, R., \& Yannopoulou, N. (2007). The nature of trust in brands: a psychosocial model. European journal of marketing, 41(9/10), 988-998. https://doi.org/10.1108/03090560710773309

Fombrun, C., \& Van Riel, C. (1997). The reputational landscape. Corporate Reputation Review, 1(2), 5-13. https://doi.org/10.1057/palgrave.crr.1540024

Fornell, C., \& Larcker, D. F. (1981). Evaluating structural equation models with unobservable variables and measurement error. Journal of marketing research, 18(1), 39-50. https://doi.org/10.1177/002224378101800104

Godey, B., Manthiou, A., Pederzoli, D., Rokka, J., Aiello, G., Donvito, R., \& Singh, R. (2016). Social media marketing efforts of luxury brands: Influence on brand equity and consumer behavior. Journal of Business research, 69(12), 5833-5841. 
https://doi.org/10.1016/j.jbusres.2016.04.181

Gouthier, M., \& Schmid, S. (2003). Customers and customer relationships in service firms: The perspective of the resource-based view. Marketing theory, 3(1), 119-143. https://doi.org/10.1177/1470593103003001007

Hair, J. F., Hult, G. T. M., Ringle, C., \& Sarstedt, M. (2016). A primer on partial least squares structural equation modeling (PLS-SEM). London, England: Sage publications. https://doi.org/10.15358/9783800653614

Helm, S., Garnefeld, I., \& Spelsiek, J. (2015). Exploring the Causal Structure Between Perceived Corporate Reputation and Consumer Satisfaction-an Experimental Investigation. Paper presented at the The 2008 Academy of Marketing Science Annual Conference, Cham, Switzerland. https://doi.org/10.1007/978-3-319-10963-3_105

Hennig-Thurau, T., Gwinner, K. P., \& Gremler, D. D. (2002). Understanding relationship marketing outcomes: an integration of relational benefits and relationship quality. Journal of service research, 4(3), 230-247. https://doi.org/10.1177/1094670502004003006

Hilton, B., Choi, C. J., \& Chen, S. (2004). The ethics of counterfeiting in the fashion industry: quality, credence and profit issues. Journal of business Ethics, 55(4), 343352. https://doi.org/10.1007/s10551-004-0989-8

Ismail, A. R. (2017). The influence of perceived social media marketing activities on brand loyalty: The mediation effect of brand and value consciousness. Asia pacific journal of marketing and logistics, 29(1), 129144. https://doi.org/10.1108/APJML-10-2015-0154

Jacoby, J., \& Chestnut, R. W. (1978). Brand loyalty: Measurement and management. New York, NY : John Wiley \& Sons Incorporated.

Jo Hatch, M., \& Schultz, M. (1997). Relations between organizational culture, identity and image. European journal of marketing, 31(5/6), 356-365. https://doi.org/10.1108/03090569710167583

Kawamura, Y. (2004). The Japanese revolution in Paris fashion. Fashion theory, 8(2), 195-223. https://doi.org/10.2752/136270404778051771

Kim, A. J., \& Ko, E. (2010). Impacts of luxury fashion brand's social media marketing on customer relationship and purchase intention. Journal of Global Fashion Marketing, 1(3), 164-171. DOI:https://doi.org/10.1080/20932685.2010.10593068

Kotler, P., Keller, K. L., Goodman, M., Brady, M., \& Hansen, T. (2019). Marketing management (4th European edition). Harlow, England: Pearson Education Limited.

Kumar, V., \& Shah, D. (2004). Building and sustaining profitable customer loyalty for the 21 st century. Journal of Retailing, 80(4), 317-329. https://doi.org/10.1016/j.jretai.2004.10.007

Loiacono, E. T. (2015). Self-disclosure behavior on social networking web sites. International journal of electronic commerce, 19(2), 66-94.

https://doi.org/10.2224/sbp.2015.43.1.1

Macintosh, G., \& Lockshin, L. S. (1997). Retail relationships and store loyalty: a multi-level perspective. International Journal of Research in marketing, 14(5), 487-497. https://doi.org/10.1016/S0167-8116(97)00030-X

Maslow, A. H. (1943). A theory of human motivation. Psychological review, 50(4), 370-396. https://doi.org/10.1037/h0054346

Mayer, R. C., Davis, J. H., \& Schoorman, F. D. (1995). An integrative model of organizational trust. Academy of management review, 20(3), 709-734. https://doi.org/10.5465/amr.1995.9508080335

Miller, K. D., Fabian, F., \& Lin, S. J. (2009). Strategies for online communities. Strategic management journal, 30(3), 305-322. https://doi.org/10.1002/smj.735

Morgan, R. M., \& Hunt, S. D. (1994). The commitmenttrust theory of relationship marketing. The Journal of marketing, 58(3), 20-38. https://doi.org/10.1177/002224299405800302

Nguyen, H. M., \& Khoa, B. T. (2019a). Perceived Mental Benefit in Electronic Commerce: Development and Validation. Sustainability, 11(23), 6587-6608. https://10.3390/su11236587

Nguyen, H. M., \& Khoa, B. T. (2019b). The Relationship between the Perceived Mental Benefits, Online Trust, and Personal Information Disclosure in Online Shopping. The Journal of Asian Finance, Economics and Business, 6(4), 261-270. https://10.13106/jafeb.2019.vol6.no4.261

Nguyen, M. H., \& Khoa, B. T. (2019c). Customer Electronic Loyalty towards Online Business: The role of Online Trust, Perceived Mental Benefits and Hedonic Value. The Journal of Distribution Science, 17(12), 102-112. https://10.15722/jds.17.12.201912.102

Nguyen, M. H., \& Khoa, B. T. (2019d). A Study on the Chain of Cost - Values-Online Trust: Applications in Mobile Commerce in Vietnam. Journal of Applied Economic Sciences, 14(1), 269-280.

Nunnally, J. C., \& Bernstein, I. (1994). The assessment of reliability. Psychometric theory, 3(1), 248-292.

Oliver, R. L. (1999). Whence consumer loyalty? Journal of marketing, 64(4), 33-44. https://doi.org/10.1177/00222429990634s105

Palmatier, R. W., Dant, R. P., Grewal, D., \& Evans, K. R. (2006). Factors influencing the effectiveness of relationship marketing: a meta-analysis. Journal of marketing, 70(4), 136-153.

https://doi.org/10.1509/jmkg.70.4.136 
Riecken, D. (2000). Personalized views of personalization. Communications of the ACM, 43(8), 26-26. https://doi.org/10.1145/345124.345133

Roberts, P. W., \& Dowling, G. R. (1997). The value of a firm's corporate reputation: How reputation helps attain and sustain superior profitability. Corporate Reputation Review, 1(1), 72-76.

https://doi.org/10.1057/palgrave.crr.1540020

Sternberg, R. J. (1997). Construct validation of a triangular love scale. European Journal of Social Psychology, 27(3), 313-335. https://doi.org/10.1002/(SICI)10990992(199705)27:3<313::AID-EJSP824>3.0.CO;2-4

Toufaily, E., Fallu, J.-M., \& Ricard, L. (2016). OCL: Online customer loyalty in the service industries: Scale development and validation. Journal of Relationship Marketing, 15(4), 269-298. https://doi.org/10.1080/15332667.2016.1209067

$\mathrm{Tu}, \mathrm{C}$. (2019). Vietnam fashion market is increasingly attractive. Retrieved July 20, from https://doanhnhanplus.vn/thi-truong-thoi-trang-vietnam-ngay-cang-hap-dan-408378.html
Turban, E., Outland, J., King, D., Lee, J. K., Liang, T.-P., \& Turban, D. C. (2017). Electronic Commerce 2018: A Managerial and Social Networks Perspective. Cham, Switzerland: Springer. https://doi.org/10.1007/978-3319-58715-8

Van der Waldt, D. R., Rebello, T., \& Brown, W. (2009). Attitudes of young consumers towards SMS advertising. African Journal of Business Management, 3(9), 444452.

Walsh, G., \& Beatty, S. E. (2007). Customer-based corporate reputation of a service firm: scale development and validation. Journal of the Academy of marketing Science, 35(1), 127-143. https://doi.org/10.1007/s11747-007-0015-7

Weigelt, K., \& Camerer, C. (1988). Reputation and corporate strategy: A review of recent theory and applications. Strategic management journal, 9(5), 443454. DOI:https://doi.org/10.1002/smj. 4250090505

Yaakop, A., Anuar, M. M., \& Omar, K. (2013). Like it or not: Issue of credibility in Facebook advertising. Asian Social Science, 9(3), 154-163.

https://doi.org/10.5539/ass.v9n3p154 